\title{
Educação face à mída: interacionismo e mediações
}

\author{
Magno Medeiros da Silva*
}

\begin{abstract}
Resumo
Os fundamentos e os resultados de algumas experiências latino-americanas na área de Educação face à Midia, especialmente as do Chile. Peru e Uruguai. Discute ainda, uma série de questões teóricas, epistemológicas e metodológicas referentes às mediações do processo de recepção midiática e ao paradigma interacionista no campo Comunicação-Educação.
\end{abstract}

Palavras-chave: Educação e Midia, mediações, recepção, paradigma interacionista.

\section{0 que é educação face à mídia}

Embora o termo Educação para os Meios venha sendo usado por vários pesquisadores latino-americanos, preferimos empregar a denominação Educação face à Mídia. Optamos por recusar a preposição "para" por entendermos que ela concede um caráter unidericional ou mesmo finalista ao conceito de Educação. A rigor, não se educa "para". mas "mediado por". Assim, parece-nos mais adequado usar-se o termo "face": é possível educar-se "face a".

A Educação face à Mídia tem por objetivo fundamental potenciar a capacidade receptiva dos indivíduos-cidadãos na perspectiva de uma interação crítica, ética, estética, axiológica e propedêutica do processo comunicativo.

Fundamentalmente, busca-se a construção de uma consciência crítica frente aos diversos processos de comunicação social. O receptor/ educando deixa de ser encarado como mero espectador dos processos midiáticos, acrítica e passivamente concebido. Ao contrário. a

* Jornalista. doutor pela USP. editor deste periódico. coordenador do Núcleo de Pesquisa em Comunicação e Informação. professor da Faculdade de Comunicação e Biblioteconomia da Universidade Federal de Goiás e do Mestrado da Faculdade de Educação da mesma instituição. E-mail: magno a facomb.ufg.br

Comun. Inf., v. 1, n. 2, p. 266-282, jull./dez. 1998 
Educação face à Mídia propõe o resgate e a reconstrução de sujeitos criativos, questionadores. conscientes de seus direitos e deveres como cidadãos, participantes de diferentes interações sociais, histórica e culturamente localizados.

Segundo o Centro de Indagación y Expresión Cultural y Artística (C'eneca )'. a İducação face à Midia propõe-se a formar uma pessoa crítica e ativa fiente aos diversos processos de comunicação em que está imersa. Trata-sc. pois. de "um processo que tende a problematizar tanto o conteúdo como a relação que estabelece o sujeito receptor com os meios de comunicação. confrontando a proposta cultural dos meios (como parte da sociedade) com a sua, esclarecendo as convergências e divergências". Com efeito, busca-se "produzir um conhecimento para a ação, na perspectiva da libertação"2.

Os primeiros programas nesta área surgiram a partir do final dos anos 60, principalmente nos EUA, Canadá, Austrália e países da Europa. Tinham por objetivo "alfabetizar" crianças e jovens em relação à linguagem audiovisual. A orientação predominante consistia, basicamente, em "enfrentar" a presença emergente dos mass media, considerados naquela época como perniciosos à saúde psicossocial, sobretudo de crianças e adolescentes. Com efeito, buscavam-se mecanismos de defesa contra as supostas conseqüências negativas provocadas pelas mensagens dos meios massivos.

Na América Latina, as primeiras experiências ocorreram no final dos anos 70. Entretanto, somente nos anos 80 é que os programas foram desenvolvidos de maneira mais sistematizada. Os quatros primeiros seminários de Educação para a Comunicação foram realizados em Santiago/ Chile(1985, soba iniciativa do Ceneca), Curitiba/Brasil(1986), em Buenos Aires/Argentina(1988)e Las Vertientes/Chile(1991).

De acordo com o Ceneca. são fins pedagógicos da Educação face à Mídia: ${ }^{3}$

- Formar uma consciência crítica, entendida como a capacidade de compreender o processo de produção da mensagem e de confrontar/discriminar o seu universo simbólico com a gama de valores irradiados pelos meios.

- Desenvolver uma atitude ativa, entendida como a capacidade de identificar/valorizar o papel que têm os mass media na vida social dos indivíduos e de reforçar a consciência de solidariedade coletiva (laços comunitários). 


\section{8}

- Desenvolver a iniciativa de influir e interferir no pólo da emissão (produção midiática).

- Liberar a criatividade e a expressividade individual-coletiva.

Quanto aos destinatários, a definição tem recaído preferencialmente sobre as crianças e os adolescentes. Isto implica. todavia, a capacitação de professores, pais e famílias. Por outro lado. tem-se priorizado trabalhos com entidades e comunidades dos setores populares.

\section{Programas de Educação face à Mídia na América Latina}

Entre as várias experiências latino-americanas nesta área, vamos destacar três programas: os de Recepção Ativa de TV do Ceneca (Chile) e do Cicosul (Peru), e o de Leitura Crítica, proposto por Mario Kaplún (Uruguai). São três bons exemplos de experiências que vêm despertando muita reflexão e, sobretudo, sugestões para a legitimação e para o aprimoramento teórico-metodológico do campo interdisciplinar Comunicação/Educação.

Coordenado por Valerio Fuenzalida e Maria Elena Hermosilla, o Programa do Ceneca foi iniciado em 1982, em escolas, movimentos sociais, grupos de produtores de vídeo e TV, usando manuais, cartilhas e trabalhos em grupo nas chamadas oficinas de capacitação.

Alguns fundamentos teóricos marcaram o desenvolvimento das experiências realizadas pelo Ceneca. Em primeiro lugar, é preciso reconhecer que o significado televisivo e as ressignificações vão sendo construídos em confronto com as percepções dos filhos, dos pais. dos vizinhos, dos colegas, em organizações civis etc. Em segundo lugar. o receptor não estabelece uma relação unívoca com o meio. mas diversificada conforme os diferentes programas e gêneros. A rigor. não existe a TV. mas TVs variadas. de acordo com as peculiaridades dos variados programas. cuja relação estabelecida é muito mais emocional do que racional.

Ademais. a situação de recepçào (o espaço do lug̣ar. da casa ) é um importante fator a ser considerado. Isto porque as condiçòes de recepção aparecem não como externas à comunicação televisiva. mas como constitutivas do processo de significação. Entre o receptor e a TV não ocorre uma relação causal e unidirecional em um ou outro sentido, mas uma relação dialética. O significado existencial é construído

Comun. Inf., v.1, n. 2, p. 266-282, jul./de=. 1998 
por um receptor culturalmente situado, interagindo com os sentidos televisivos de um dado gênero específico.

Outro fator fundamental é o contexto social: para os pobres, por exemplo, a TV é uma das poucas alternativas de lazer disponível, e a publicidade de certos produtos aparece como uma oportunidade de consumo ilusória. irreal.

A apropriação da programação é ambígua: pode confirmar e reforçar certas tendências de autodesvalorização. como ocorre com o homem do campo. com o negro, com a mulher. com o idoso, com o operário, com o índio. com o pobre etc. Portanto, as mediações culturais importantes do processo de recepção televisiva são, principalmente, a vida grupal, o contexto sócio-econômico e os gêneros televisivos.

Segundo Fuenzalida e Hermosilla. ${ }^{+}$os objetivos básicos do Programa de Recepção Ativa do Ceneca são:

- Formar receptores críticos e seletivos, capazes de tomar distância ideológica e valorativa ante às emissões.

- Valorizar as reelaborações que faz o receptor, em lugar de pretender ensinar o suposto "verdadeiro significado" dos programas.

- Valorizar as apropriações semantizadoras e as expressividades culturais dos grupos sociais.

- Estimular a constituição de atores sociais capazes de demandar ativamente uma orientação e uma programação de TV adequadas aos seus interesses. motivações e necessidades.

Quanto ao Programa de Recepção Ativa do Centro de Investigação em Comunicação Social da Faculdade de Ciências da Comunicação da Universidade de Lima (Cicosul). ${ }^{5}$ salientamos que este tem trabalhado, a partir de 1983, principalmente com estudantes, entre 10 e 15 anos, de escolas públicas e particulares de zonas muito pobres.

Coordenado por Teresa Quiroz. o programa tem-se pautado por uma função educativa, da qual participam a família. o bairro, a televisão. o rádio, o cinema, a igreja, os partidos políticos, considerando o lugar que ocupam na proposta de valores, atitudes e expectativas sociais.

Entende-se que a recepção ativa incentivará a confrontação de gostos espontâneos e a desmistificação do que os meios propõem, 


\section{0}

explicitando as diferenças entre uns e outros e abrindo espaços experimentais, onde o receptor possa construir suas próprias histórias.

Já o Programa de Leitura Crítica, ${ }^{6}$ desenvolvido na Universidade da República (Uruguai), nasceu como uma proposta metodológica formulada por Mario Kaplún. Para ele, toda autêntica formação crítica de receptores pressupõe uma tomada de consciência em relação à ideologia subjacente às mensagens, entendida esta como um conjunto de valores e crenças que articulam as condutas sociais cotidianas.

Entretanto, ressalta Kaplún, os meios não são criadores de ideologia, mas veiculadores e difusores privilegiados da ideologia dominante que entranha todo o tecido social. O êxito da hegemonia ideológica depende de uma certa cooperação, de uma certa cumplicidade por parte dos receptores.

De qualquer forma. os meios são massivamente consumidos porque respondem a necessidades dos receptores, ainda que tais respostas sejam enganadoras ou falseadas. Contudo, é preciso admitir-se que a ideologização não é privilégio das mensagens conservadoras. mas também daquelas supostamente denuncistas e de contestação.

\section{Procedimentos metodológicos em Educação face à Mídia}

O delineamento metodológico do Ceneca baseia-se, principalmente, no enfoque lúdico, já que um veículo da natureza da televisão dificilmente poderia ser encarado metodologicamente meramente a partir do reino do "logos". Os jogos de simulação absorvem por completo o jogador e representam uma ação livre, executada e sentida como se o receptor estivesse fora da vida cotidiana. Os indivíduos são convidados a "brincar", elaborando, por exemplo, um capítulo de telenovela, um spot publicitário, um telejornal. Assim. os jogos buscam a criação e a construção de um novo saber.

Os jogos são trabalhados em oficinas de capacitação, onde são formados subgrupos de aprendizagem. Utilizam-se materiais diversos: recortes de jornais e revistas, fotografias, roupas e disfarces, instrumentos musicais, utensílios domésticos para fazer ruido. papel, cartolinas, isopor, produtos de maquiagem. pincéis etc.

Após os jogos lúdicos, ocorrem a discussão e a síntese. Pensa-se sobre os conceitos, compara-se o realizado com as mensagens da TV.

Comun. Inf., v.l, n. 2, p. 266-282, jul./de=. 1998 
relaciona-se. sintetiza-se. Após a síntese. avalia-se a experiência realizada e elaboram-se propostas de ação.

$\Lambda$ s oficinas pedagógicas do Ceneca contam com a participação do "facilitador" ou "animador". que tem por função coordenar os debates e as discussòes. promover a avaliaçào. sempre em clima cordial e sério. não se preocupando em "ensinar". mas em promover descobertas. Trabalha-se com o apoio de manuais. que não possuem o formato de cartilhas e nem possuem conteúdos programáticos fechados, rígidos como receituários. Os manuais não devem ser uma camisa-deforça. mas. ao contrário. um instrumento didático instaurador. capaz de adaptar-se flexivelmente a inquietudes e interesses diversos.

A metodologia do Ceneca possui muito pontos em comum com a do Cicosul. principalmente na ênfase aos aspectos lúdicos. Nas oficinas de capacitação, são utilizados os formatos veiculados pela TV comercial, isto é, os gêneros preferidos, buscando-se sempre motivar e estimular a participação espontânea.

Trabalha-se com dinâmicas de grupo, com a distribuição prévia de fichas de trabalho, e com a intervenção moderada do facilitador ou animador das oficinas. Durante os trabalhos nas oficinas pedagógicas do Cicosul, interessa verificar: ${ }^{7}$

- o grau em que o grupo discrimina, julga e critica os dados transmitidos:

- a sensibilidade com relação às opiniões e compreensões alheias;

- o nível de compromisso com as atividades propostas;

- a sensação de êxito ou fracasso grupal; o medo, a incerteza, a insegurança:

- o grau interno de tolerância mútua:

- o papel dos líderes no grupo:

- a função do humor nas atividades coletivas:

- a linguagem não verbal (gestos, expressões faciais, flexões de voz etc.).

Qualquer gênero televisivo pode propiciar um laboratório instigante. A telenovela, por exemplo. pode ser trabalhada tendo por objetivos, entre outros: 1) reconhecer a telenovela como um dos campeões do entretenimento por contar histórias, abordando temas cotidianos; 2) reconhecer que a telenovela nos atrai basicamente porque nos emociona através da dramatização do conflito. 


\section{2}

As dinâmicas de grupo podem explorar: 1) relato de experiências, a partir, por exemplo, de frases polêmicas e até absurdas; 2) produção de materiais, como a redação de um capítulo de telenovela. Em seguida, parte-se para a discussão, a síntese e a avaliação.

Por sua vez, a metodologia empregada por Mário Kaplún em suas oficinas de Leitura Crítica também procura explorar os recursos audiovisuais. Através do método indutivo e participativo, cada participante vai sendo levado a descobrir por si mesmo a mensagem metacomunicada. Estimula-se, assim, o processo de autodescoberta. Com efeito, o animador não deve adiantar conclusões, nem substituir os participantes em sua reflexão, nem se abster de sua opinião. no momento oportuno. Deve abolir os termos técnicos, ser amistoso e fraterno, estimular o debate e os avanços alcançados e sempre saber escutar.

Pauta-se, ademais, por uma sequência gradual e progressiva das atividades, das mais simples às mais complexas, utilizando-se instrumentos diversos de análise: psicologia, teoria da comunicação, sociologia, semiologia, antropologia etc. Opta-se por atividades sensíveis/ acessiveis, explorando experiências do próprio grupo e dando relevância aos aspectos vivenciais: os participantes devem envolver-se numa auto-análise, verificando o seu próprio comportamento e os usos e consumos que ele próprio faz.

Quanto às atividades práticas, os passos seguem o seguinte roteiro: apresentação do tema; utilização de recursos audiovisuais; elaboração de perguntas para discussão; trabalho em equipes (reflexão individual e discussão); confronto das respostas das equipes; diálogo sobre a revisão do material, os aportes do animador e a sistematização dos aportes das equipes. Deve-se procurar ir sempre aprofundando as análises, elaborando recapitulações, avaliações e sugestões.

\section{Processos educativos em oficinas pedagógicas}

Os trabalhos realizados em Educação face à Mídia são operacionalizados em oficinas pedagógicas, que são espaços onde se exercitam processos de ensino-aprendizagem, conforme metodologia anteriormente apresentada. Nestas, não se ministram aulas, muito menos palestras. $\mathrm{O}$ fundamental é a troca de experiências, o debate pro-

Comun. Inf., v.1, n. 2, p. 266-282, jul./dez. 1998 
dutivo. o diálogo franco, a relação afetiva e. sobretudo. a construção ativa e criativa de produtos e conhecimentos.

No caso do Programa de Recepção Ativa do Ceneca. as oficinas seguem o seguinte fluxograma: ${ }^{8}$

- Preparando-se para a sessão (5 min. ). em que se discute:

- De que estamos falando?

- (uais os objetiros a serem alcançados"?

- () yue mais é necessário saber sobre o nosso trabalho?

- (Quais os materiais necessários?

- Trabalhando com o grupo (2 horas). em que se pratica:

- Dinâmicas de comunicação não-verbal: exercícios de respiração. jogos de confiança. brincadeira de roda, ou outra qualquer (20 min.):

- Apresentação de experiências, que são selecionadas e anotadas (10 minutos);

- Jogos: os subgrupos entram em ação para pensar e produzir, por exemplo. um capítulo de telenovela, um spot publicitário, um programa de rádio etc. ( $1 \mathrm{~h} 15 \mathrm{~min}$.):

- Discussão e síntese (15 min.).

- Avaliação (15 min.):

- O que descobrimos? O que aprendemos?

- Quais as dificuldades encontradas?

- Quais as falhas? Quais os acertos?

Nas oficinas do Cicosul. os processos de ensino-aprendizagem intentam: ${ }^{9}$

- Provocar um distanciamento entre os conteúdos da TV e a realidade dos receptores.

- Incentivar a comparação entre os diversos programas.

- Situar os receptores como potenciais produtores de mensagens.

- Servir-se das experiências das oficinas para multiplicar o processo de aprendizagem.

Já nas oficinas de Leitura Crítica, proposto por Kaplún, trabalhase com educandos a partir dos 16 anos em turmas de 15 e 25 participantes. O programa, que tem carga horária de 25 horas/aula (sessões semanais de 3,5 horas), explora a publicidade. as canções populares, os contos infantis, os seriados de TV. os filmes do cinema, os telejornais, as telenovelas etc.

Comun. Inf.. v.l, n. 2, p. 266-282, jul./dez. 1998 


\section{4}

\section{O legado do paradigma interacionista}

Das três experiências latino-americanas, aqui discutidas, percebese uma inserção ao paradigma interacionista. ${ }^{10}$ Nesta perspectiva, buscam-se, sobretudo, procedimentos e intervenções problematizadores e dialógicos, enfatizando técnicas ativo-participativas que desvelem interconexões e fomentem a dinâmica de grupo e a autoprodução.

Segundo Orozco Gómez," o paradigma interacionista busca a interconexão de elementos que podem estar influindo em algo que resulte ou suceda de determinada maneira. Então, o importante é ver que fatos e fenômenos estão interconectados com outros e interagindo para produzir algo. Não importa se são todos os elementos ou se são uns tantos: o que interessa realmente é ver as conexões entre uns e outros. Neste sentido, o trabalho do investigador é, pois, associar certos elementos para produzir um conhecimento sobre eles. que antes estava ou se apresentava como dissociado: tal conexão é que permitirá a produção de um conhecimento distinto.

Seguindo esta linha de atuação, ver-se-á que os fatos e fenômenos diferem substancialmente dependendo do enfoque que se estabelece: o das fragmentações ou o das interconexões.

Porém, existem vários tipos de interações possíveis, entre as quais: fenômenos/fenômenos, fenômenos/sujeitos, sujeitos/sujeitos. No primeiro caso, poderíamos interconectar, por exemplo, programação televisiva e política comunicacional. No segundo caso, poderíamos interagir exposição televisiva e comportamento dos receptores. Finalmente, poderíamos pensar na interação entre comunidades diversas de receptores midiáticos.

$\mathrm{Na}$ área de Educação face à Mídia. entendemos que não basta estabelecer interações entre fatos e fenômenos. negligenciando-se ou colocando-se os receptores/educandos em segundo plano. Mais adequado é aprofundar. dialeticamente. a pesquisa e as práticas interativas entre os emissores/receptores e os educadores/ educandos.

Entende-se que os trabalhos em grupo propiciam mais oportunidades de interação participativa. espírito de cooperação. debate. controvérsias. Conflito e tensão também podem se tornar produtivos. à medida que garantam uma maior transparência à diversidade de pon-

Comun. Inf., 1.1. n. 2, p. 266-282, jul./dez. 1998 
tos de vista. Portanto, pode-se construir momentos pedagogicamente enriquecedores em termos de ensino-aprendizagem.

Como afirma Vygotski, ${ }^{12}$ os processos cognitivos são decorrentes de variadas e dinâmicas formas de interação. Ou seja, o conhecimento é reelaborado a partir da relação social que o sujeito estabelece com o mundo e com outros sujeitos. A subjetividade é dialógica, uma vez que é reconstruída a partir da relação intrapsicológico/interpsicológico. A configuração do interno (individual) depende de sua relação dialógica com o externo (social). Neste jogo de fluxos, influências e confluências encontra-se a presença dos fatores intervenientes, as mediações, cujo conceito veremos mais adiante.

Os programas de Educação face à Mídia (sobretudo o do Ceneca) valorizam bastante certos procedimentos lúdicos no processo ensinoaprendizagem. As brincadeiras, além de descontrair e facilitar a interação entre as pessoas, criam um ambiente fecundo em termos de construção imaginária, facilitando a imaginação criativa e a interpretação cênica de papéis e modelos sociais.

Fundamentalmente, faz-se uma opção clara pela investigação participativa e interativa. Neste sentido, incorpora-se a avaliação como um componente que fornece informações para ir validando as propostas e ir tomando decisões.

As oficinas pedagógicas constituem espaços apropriados para a criação, produção, discussão, aprendizagem. Através delas, os receptores/educandos podem desenvolver atividades práticas, produzindo e/ou avaliando produtos midiáticos e educacionais. Ademais, priorizase a capacitação de agentes multiplicadores.

\section{Interacionismo e mediações nos processos de recepção}

() paradigma interacionista é um campo fértil para estudos, pesquisas e programas que exploram os processos de recepção midiática. Vale dizer. as mediaçōes do campo Comunicação-Educação.

Im primciro lugar. é preciso esclarecer que a Teoria da Recepção tem por objetiv o resgatar o sujeito do processo de comunicação (antes dissimulado. oculto). buscando interpretar os espaços de produção, interpretação, ressemantização e negociação incessante de sentidos. O receptor deixa de ser visto como passivo. como mero consumidor de supérfluos culturais ou produto massificado apenas porque consome. 


\section{6}

De acordo com Mauro Wilton de Sousa. no bojo da Teoria da Recepção. "os meios de comunicação de massa são vistos não apenas como veículo, mas como expressão de uma instância pública que indaga e também reconhece os espaços de construção de valores. ainda que sejam valores grupais. Tais espaços são ao mesmo tempo de negociação e de debates.". ${ }^{3}$

Martín-Barbero afirma que a recepção não é apenas uma etapa do processo de comunicação. mas um lugarar novo. Não apenas um lugar de chegada do processo comunicativo. mas também um lugar de partida. isto é. um espaço de produção de sentido - o sentido que estara abolido. Segundo o autor. trata-se. pois. de uma oposição ao modelo mecânico estímulo-resposta $(E>R)$. em que não há nem verdadeiros atores nem verdadeiros intercâmbios. ${ }^{14}$

Entretanto. não se pode bem compreender as práticas de recepção midiática sem investigar e interpretar as mediações. A rigor, não existe recepção sem mediação. Entendendo-se por mediação o lugar e suas condições interativas onde se produzem sentidos ao processo comunicativo. $^{15}$

Orozco Gómez ${ }^{16}$ define seis premissas essenciais do processo de recepção midiática:

- A recepção é necessariamente um processo mediado:

- A recepção é interação (com o meio. com o gênero, com a mensagem. com a cultura. com as instituições etc.):

- A exposição aos meios é condição necessária, mas não suficiente (é preciso considerar não apenas a quantidade como também a qualidade da exposição aos meios):

- O sujeito receptor é um múltiplo agente social (portanto. é partícipe de outros processos e interações):

- A comunicação se produz no processo de recepção (campo das ressemantizações, reelaborações, negociações, polissemias):

- $O$ receptor vai-se construindo de distintas maneiras (ele não nasce. mas se faz e se transforma: ele não é estático, mas dinâmico).

É importante destacar que o processo de recepção é constituído não por uma mas por "múltiplas mediações". Dentre estas, Orozco ${ }^{17}$ destaca cinco: 
1) Mediações individuais (esquemas mentais, através dos quais percebemos, assimilamos, processamos, prestamos atenção, memorizamos etc.);

2) Mediações institucionais (família, escola, trabalho, igreja, entidades etc.);

3) Mediações massmediaticas (TV, rádio, jornal, revista, internet etc.):

4) Mediações situacionais (audiência solitária, em grupo, em família, em casa, no cinema; situação de busca de informações ou de entretenimento: situação de cansaço, de stress etc.);

5) Mediações de referência (idade, gênero, etnia, classe social etc.).

Note-se que o conceito de "múltiplas mediações" adequa-se bem ao paradigma interacionista, uma vez que pressupõe todo um conjunto de elementos que, interligados, mantêm relações de interdependência, uns interferindo sobre os outros. As mediações institucionais, ou as individuais, ou as de referência, ou outras, todas elas possuem o seu peso na rede interativa das mediações. Não existem. pois, uma causalidade e uma finalidade únicas. A reapropriação de sentidos é polissêmica, descentralizada, múltipla, plural.

Trata-se, então, de uma concepção que se aproxima mais à noção de conhecimento como rede e não como cadeia. ${ }^{18} \mathrm{Na}$ rede. não existem pontos seqüenciais ou hierárquicos; todos se somam e se dividem na constituição da totalidade.

É importante observar que as premissas do processo de recepção são basicamente interativas. Primeiro, porque não existe recepção sem mediação. isto é, sempre existe a presença de um terceiro que interage nos processos de comunicação/educação. Segundo, porque, como foi dito literalmente. é preciso considerar que se trata de interações diversas: com o meio, com os gêneros. com as instituições etc. Devese considerar. ainda, que o sujeito-receptor não é um ser estático, estável. mas dinâmico, dialético. partícipe de múltiplos processos e interações sociais.

E mais: a comunicação se processa no campo interativo da recepção, porque é aí que ocorre. efetivamente, a produção de sentidos. Ou seja, é no campo da recepção que o sujeito reinterpreta,

Comun. Inf., v.l, n. 2, p. 266-282, jul./de=. 1998 


\title{
278
}

ressemantiza, reapropria. e também se permite autoconstruções (formação do seu self f).

Neste contexto. é preciso resgatar o conceito de mundo vivido. de Habermas. ${ }^{19}$ Atinal. é no campo da recepção que se irá compreender melhor o ambíguo. contraditório e disforme imaginário do sujeito: sua sociabilidade. seu cotidiano. seus desejos e necessidades.

Por mundo vivido entenda-se a dimensão das experiências partilhadas. da perspectiva subjetiva dos atores. das relaçòes dialógicas. dos questionamentos de verdades. da renegociação de interações sociais.

Segundo Habermas. o mundo vivido não pode ser "colonizado" pelo mundo sistêmico (espaço da tecnocracia. da burocracia. da racionalidade técnica, da monetarização, da exclusão do diálogo, das forças produtivas, da razão instrumental).

Para que o mundo sistêmico não "fagocite" o mundo vivido, é preciso que a razão instrumental deixe de neutralizar ou ofuscar a razão comunicativa (razão subjetiva. autônoma. espontânea, implementada socialmente no processo de interação dialógica dos sujeitos, notadamente através dos procedimentos argumentativos, do discurso).

O mundo vivido é o campo onde, de fato, reside o sujeito-receptor, imerso em sua cotidianidade. Neste, segundo Habermas, todas as verdades podem ser questionadas: todas as normas e valores devem ser justificados; todas as relações sociais devem ser renegociadas (busca do consenso e da reciprocidade). Trata-se de um espaço onde deve imperar a forma dialógica da crítica. de modo que a verdade irá resultar de um diálogo entre pares. seguindo a lógica do melhor argumento.

Diante do exposto, cabe inferir que é justamente no espaço das interações, das mediações, do mundo vivido, que melhor se pode delinear, interpretar e compreender a dimensão dinâmica do sujeito-educando. Neste sentido, processo de recepção midiática e as experiências e pesquisas em Educação face à Mídia encontram adequada guarida teórico-metodológica no contexto do paradigma interacionista.

\begin{abstract}
The author approaches the fundamental and the outcomes of some LatinAmerican experiences in the field of Education before the Media, especially the ones from Chile, Peru and Uruguay. It's discussed, yet, a series of theoretical.
\end{abstract}

Comun. Inf.. v.1, n. 2, p. 266-282, jul./dez. 1998 
epistemological and methodolocial questions related to the mediations of the process of medial reception and to the interative paradigm in the CommunicationEducation.

Key words: Education before the Media; mediations; processes of reception; interative paradigm.

\section{Notas}

I Entidade chilena que atua na área de Educação para os Meios desde o início dos anos 80 .

2 CENECA. Educación para la comunicación. Santiago: Unesco, Unicef, 1992. p. 20. (Tradução livre do autor)

3 Ibid., p. 20-I.

4 FUENZALIDA, V.e HERMOSILLA, M.E. Programa de Recepción Activa de TV. In CENECA. op. cit., p. 80-1.

5 QUIROZ, T. Proyecto de Recepción Activa de la Televisión. In CENECA, op. cit., p. 103-13. 213.

6 KAPLÚN, M. Metodo de Lectura Crítica. In CENECA, op. cit., p. 196-

7 QUIROZ, op. cit., p. 107.

8 FUENZALIDA, op. cit., p. 89.

9 QUIROZ, op. cit., p. 109.

10 Segundo Orozco Gómez, existem quatro grandes paradigmas de produção de conhecimentos: positivista, realista, hermenêutico e interacionista. Para o paradigma positivista só existe um conhecimento verdadeiramente científico: o verificável, o quantificável, o comprovável. Os demais não poderiam ser "validados cientificamente", portanto, não seriam conhecimentos "confiáveis". O positivismo quer fazer explícito que o único conhecimento válido é o conhecimento verificável, e não o conhecimento obscuro, ininteligível pelos sentidos. Consiste em estabelecer predições, isto é, formular uma série de hipóteses no sentido de se predizer que algo possa ocorrer e logo comprovar ou verificar que, de fato, ocorreu. É utilizado com maior ênfase nas ciências exatas e naturais (daí ser chamado também de paradigma naturalista ou mesmo predicionista). Já para o paradigma realista, o que importa, essencialmente, é chegar às causas dos acontecimentos, chegar às explicações últimas de tais ou quais fatos e fenômenos. A rigor, trata-se de uma variante do paradigma positivista, já que também se preocupa bastante com o aspecto quantitativo (os resultados que possam ser matematicamente demonstráveis). Mas o paradigma realista tem, certamente, o seu próprio status: a explicação empírica como fundamento maior. No campo da comunicação, faz uso do paradigma realista a maioria das pesquisas sobre os efeitos dos meios de massa. Este tipo de pesquisa tem buscado explicar os efeitos que tais meios causam na audiência. Por outro lado, o paradigma hermenéutico dá um maior peso não ao que é,

Comun. Inf., v.1, n. 2, p. 266-282, jul./dez. 1998 


\section{0}

mas à interpretação do que é. O paradigma hermenêutico de algum modo diz: "não interessa chegar a um acontecimento objetivo, senão chegar a um conhecimento consensuado". Ou seja: o que importa é a visão, o ponto de vista, a interpretação que as pessoas têm acerca do mundo. da sociedade e da vida. Tal interpretação é feita a partir do imaginário social de uma determinada cultura. A lógica já não está em tratar de obter o conhecimento objetivo, positivista ou realista dos paradigmas anteriores, mas um conhecimento que permita ao investigador conhecer o que está se passando com o seu objeto de estudo. $\mathrm{O}$ importante é, de fato, a interpretação que o pesquisador faz do que está estudando. Cf. OROZCO GÓMEZ, Guillermo. La investigación en comunicación desde la perspectira cualitativa.Guadalajara: Facultad de Periodismo y Comunicación Social de Universidad Nacional de La Plata, Instituto Mexicano para el Desarrollo Comunitario, 1997.

11 Ibid., p. 36-6.

12 VYGOTSKI, L. Formação social da mente. São Paulo: Martins Fontes, 1998; Pensamento e linguagem. São Paulo: Martins Fontes, 1995.

13 SOUSA, M.W. (org.). Sujeito, o lado oculto do receptor. São Paulo: Brasiliense, 1995, p. 35.

14 MARTÍN-BARBERO, J. América Latina e os anos recentes: o estudo da recepção em comunicação social. In SOUSA, op. cit., p. 40.

15 Martín-Barbero define três mediações fundamentais, manifestadas culturalmente: socialidade, ritualidade e tecnicidade. Cf. MARTÍN-BARBERO, J. De los medios a las mediaciones. $3^{\text {a }}$ ed. Naucalpan, México: Gustavo Gili, 1993.

16 OROZCO GÓMEZ, G. La investigación de la Recepción y la Educación para los Medios: Hacia una articulación pedagogica de las mediaciones en el processo comunicativo. In CENECA, op. cit., p. 293-5.

17 Id., La investigación en comunicación desde la perspectiva cualitativa. op. cit., p. 116-8.

18 MACHADO, N. J. Epistemologica e didćitica. São Paulo: Cortez. 1996.

19 HABERMAS, J. Teoria de la Ación ('omunicativa: complementos y estudios previos. Madrid: Cátedra, 1989.

\section{Referências bibliográficas}

ANG, Ien. Culture et Communication: Pour une critique ethnographique de la consommation des médias dans le système médiatique transnacional. In: HERMĖS Cognition, Communication. Politique, Paris: n. 11-12. 1993, p. 7593.

BARROS FILHO, Clóvis. Ética na Comunicação: da informação ao receptor. São Paulo: Moderna, 1995

BOUGNOUX, Daniel. Introdução às ciências da informação e da comunicação. Petrópolis; Vozes, 1994.

CANCLINI, Néstor García. Consumidores e cidadãos: conflitos multiculturais da globalização. Rio de Janeiro: Ed. UFRJ, 1995.

Comun. Inf., v.1, n. 2, p. 266-282, jul./dez. 1998 
CENECA. Educación para la comunicación. Santiago: Unesco, Unicef, 1992.

CERTEAU, Michel. A invenção do cotidiano. 1: Artes de fazer. Petrópolis, Vozes, 1994.

COMUNICAÇÃO \& EDUCAÇÃO. Revista da Escola de Comunicações e Artes. São Paulo: Moderna, n. 7 (set./dez. 1996) e n. 12 (maio/ago. 1998)

CONGRESSO INTERNACIONAL SOBRE COMUNICAÇÃOEEDUCAÇÃO I $^{\circ}$. Multimidia e educação em um mundo globalizado. São Paulo, 20 a 23 de maio de 1998. In: Revista de Ciéncia e Tecnologia (Centro de Pesquisa e Tecnologia do Centro Universitário Salesiano de São Paulo), v. 1, n. 2, maioago/ 1998.

DEMO, Pedro. Questões para a teleducação. Petrópolis, Vozes, 1998.

DURAND, Gilbert. L imaginaire: Essai sur les sciences et la philosofie de I'image. Paris: Hatier, 1994.

FERRÉS, Joan. Vïdeo e éduciçč̃o. Porto Alegre: Artes Médicas, 1996.

FREIRE, Paulo. Pedagogia do oprimido. Rio de Janeiro: Paze Terra, 1981.

FUENZALIDA, Valerio, y HERMOSILLA, Maria Elena. El televidente activo: Manual para la Recepción Activa. Santiago: CENECA, 1991.

FUENZALIDA, V. e HERMOSILLA, M.E. Programa de Recepción Activa de TV. In CENECA. Edacacion parala commicacion. Santiago: Unesco, Unicef, 1992.

GARCÍA CANCLINI, Néstor. C'onsumidores e cidadãos: conflitos multiculturais da globalização. Rio de Janeiro: Ed. UFRJ, 1995.

GARCIA CANCLINI, Nestor. Culturas hibridas: estratégias para entrar e sair da modernidade. São Paulo: Edusp, 1997.

HABERMAS, J. Teoria de la tción Comnnicativa: complementos y estudios previos. Madrid: Cátedra, 1989.

JENSEN, Klaus B., ROSENGREN, Karl E. Cinq traditions à la recherche du public. HERAIESCognition, Communication, Politique, Paris: n. 11-12. 1993, p. 281310.

KAPLÚN, M. Metodo de Lectura Crítica. In CENECA. Educación para la communicacion. Santiago: Unesco. Unicef, 1992.

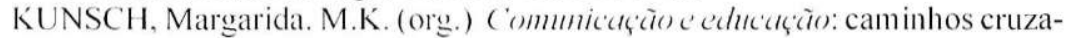
dos. São Paulo: L oyola. 1986.

I.I:VY. Pierre. I intiligincia colctira: por uma antropologia do ciberespaço. Sào Paulo: logola. 1998.

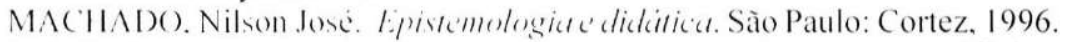

MAIIIS()I.I. M. I (ommemplacion do mundor. Porto Alegre: Artes e Ofícios, 1095 .

MAFIESOI.I. Michel. Mofunder das aparincias. Petrópolis, Vozes, 1996.

MARTIN-BARBERO. Jesus. Délos medios alas medickiones. $3^{3} \mathrm{ed}$. Naucalpan, México: Gustavo Gili. 1993.

MARTIN-BARBERO. Jesús. América Latina e os anos recentes: o estudo da recepção em comunicação social. In SOUSA, M. W. (org.) Sujeito, olado oculto doreceptor. São Paulo: Brasiliense, 1995.

Comun. Inf., 1:1, n. 2. p. 260-282. jul./de=. 1998 
MATTELART, Armand e MATTELART. Michèle. História das Teorias da Comunicação. Porto: Campo das Letras, 1997.

MELO, José M. Teoria da comunicaçào: paradigmas latino-americanos. Petrópolis, Vozes, 1998.

MIĖGE, B. La pensée communnicutionnelle. Grenoble: Presses Universitaires de Grenoble, 1995.

MORLEY, David. Television. andiencial yestudios culturales. Buenos Aires: Amorrortu, 1996.

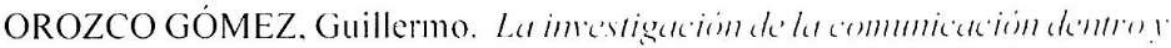
fuera de America Latina. Buenos Aires: Facultad de Periodismo? Comunicación Social de Iniversidad Nacional de La Plata. 1997.

OROZCO GÓMES, Guillermo. La investigation c'n communicusion descke la perspectiva cualitariva. Guadalajara: Facultad de Periodismo y Comunicación Social de Universidad Nacional de La Plata, Instituto Mexicano para el Desarrollo Comunitario, 1997.

OROZCO GÓMES, Guillermo. La investigación de la Recepción y. la Educación para los Medios: Hacia una articulación pedagogica de las mediaciones en el processo comunicativo. In CENECA. Educación para la Comunicación. Santiago: Unesco, Unicef, 1992.

QUIROZ, Tereza. Proyecto de Recepción Activa de la Televisión. In CENECA. Edacación para la comunicación. Santiago: Unesco, Unicef, 1992.

SFEZ, Lucien. Crítica da comunicaçcão. São Paulo: Loyola, 1994.

SOUSA, Mauro W. (org.) Sujeito, o lado oculto do receptor. São Paulo: Brasiliense, 1995.

WILLIANS, Raymond. Cultura. Rio de Janeiro: Paze Terra, 1992.

WOLF, Mauro. Teorius das comunicaçũo. Lisboa, Ed. Presença, 1995. 